\title{
Raising Climate-Resilient Embolden Rice (Oryza sativa L.) Seedlings during the Cool Season through Various Types of Nursery Bed Management
}

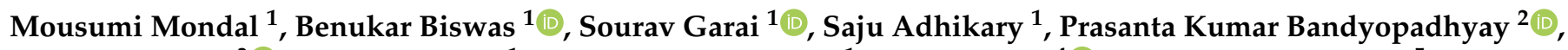 \\ Sukamal Sarkar $^{3}{ }^{\mathbb{D}}$, Hirak Banerjee ${ }^{1}$, Koushik Brahmachari ${ }^{1}$, Sagar Maitra ${ }^{4} \mathbb{D}$, Tanuj Kumar Mandal ${ }^{5}$, \\ Ahmed Gaber ${ }^{6, *(\mathbb{D}}$, Yusuf S. Althobaiti ${ }^{7}$ (D) Bassem M. Raafat ${ }^{8}$ and Akbar Hossain ${ }^{9, *(D)}$
}

Citation: Mondal, M.; Biswas, B.; Garai, S.; Adhikary, S.; Bandyopadhyay, P.K.; Sarkar, S.; Banerjee, H.; Brahmachari, K.; Maitra, S.; Mandal, T.K.; et al. Raising Climate-Resilient Embolden Rice (Oryza sativa L.) Seedlings during the Cool Season through Various Types of Nursery Bed Management. Sustainability 2021, 13, 12910. https:// doi.org/10.3390/su132212910

Academic Editor: Aureliano C. Malheiro

Received: 9 October 2021

Accepted: 15 November 2021

Published: 22 November 2021

Publisher's Note: MDPI stays neutral with regard to jurisdictional claims in published maps and institutional affiliations.

Copyright: (c) 2021 by the authors. Licensee MDPI, Basel, Switzerland. This article is an open access article distributed under the terms and conditions of the Creative Commons Attribution (CC BY) license (https:/ / creativecommons.org/licenses/by/ $4.0 /)$.
1 Department of Agronomy, Bidhan Chandra KrishiViswavidyalaya (BCKV), Nadia 741252, India; mou.mousumi98@gmail.com (M.M.); kripahi@yahoo.com (B.B.); garai.sourav93@gmail.com (S.G.); sajuadhikary1@gmail.com (S.A.); hirak.bckv@gmail.com (H.B.); brahmacharis@gmail.com (K.B.)

2 Department of Agricultural Chemistry and Soil Science, Bidhan Chandra KrishiViswavidyalaya (BCKV), Nadia 741252, India; pkb_bckv@rediffmail.com

3 Office of the Assistant Director of Agriculture, Bhagwangola-II Block, Directorate of Agriculture, Government of West Bengal, Murshidabad 742135, India; sukamalsarkarc@yahoo.com

4 Department of Agronomy, Centurion University of Technology and Management, Paralakhemundi 761211, India; sagar.maitra@cutm.ac.in

5 School of Agriculture and Allied Sciences, Neotia University, Sarisha 743368, India; tanujkumar.mandal@tnu.in

6 Department of Biology, College of Science, Taif University, P.O. Box 11099, Taif 21944, Saudi Arabia

7 Department of Pharmacology and Toxicology, College of Pharmacy, Taif University, P.O. Box 11099, Taif 21944, Saudi Arabia; ys.althobaiti@tu.edu.sa

8 Department of Radiological Sciences, College of Applied Medical Sciences, Taif University, P.O. Box 11099, Taif 21944, Saudi Arabia; bassemraafat@tu.edu.sa

9 Department of Agronomy, Bangladesh Wheat and Maize Research Institute, Dinajpur 5200, Bangladesh

* Correspondence: a.gaber@tu.edu.sa (A.G.); akbarhossainwrc@gmail.com (A.H.)

Abstract: Facing cold stress is amajor constraint in seedling production during the winter season as, most particularly in recent times due to uncertain climatic conditions, no sustainable technology has been reported that could be easily adopted by farmers withlimited resources. Therefore, field experiments were carried out during winter 2017-2018 and 2018-2019 at the Central Research Farm of Bidhan Chandra KrishiViswavidyalaya, West Bengal, India to study the growth, survival potential, yield and nutritional and biochemical properties of boro rice seedlings as influenced by two seedbed management practices viz. conventional seedbed (farmers' practice) and improved seedbed (polythene protected with micronutrient supplementation). The major objective was to lower the nurserybed duration without compromising seedlings' health and to studythe economic viability during the winter season. The experiment was laid out in ten experimental units and deployed anindependent-sample t-test to compare the performance of the seedlings. The microclimatic changes were also itemized from both seedbeds. The seeds sownunder improved nursery conditions resulted in better seedling emergence $(\sim 90 \%)$ and survival percentage $(\sim 85 \%)$ as compared to the conventional seedbed $(\sim 70 \%$ and $65 \%)$. Growth attributes in terms of plant height, biomass accumulation, root characteristics, tiller count, and growth rate were observed to be better from the polythene-protected nursery bed. Theimproved nursery bed accounted for $20 \%$ higher seedling count at the time of transplantation over the conventional bed. The microclimatic situation under a polythene covering was also favorable for germination and seedling growth. Maximum nutrient (N, P, and K) concentrations, as well as chlorophyll content, wererecorded from improved seedlings. Results suggested that the improved seedbed management was apotential alternative toearly embolden seedling production during the winter to avoid climatic abnormalities. Most importantly, improved seedbeds ensured a comprehensive route from germination to healthy seedling production without any failure in thesmalltime window, which involvedless input as well as cost involvement. This technique could diffusethe problem oflate sowing conditions in the rice-rice cropping system. 
Keywords: polythene covering; seedbed management; winterrice; nutrient uptake; soil temperature

\section{Introduction}

Rice has had a vital role in shaping cultures, societies, and industries. Globally, rice is grown in $\sim 162 \mathrm{Mha}$, comprising $12 \%$ of the world's arable lands [1]. It provides up to $50 \%$ of the dietary caloric supply for millions in Asia [2], contributing significantly to the sustainable development goals (SDGs) of hunger and poverty reduction [3]. India is the second-largest producer, accounting for 177.64 million tonnes $(\mathrm{Mt})$ of rice annually from 43.79 Mha [4], out of which winter (rabi) rice comprises14.29 million tons, while the remaindercomesfrom rainy (kharif) rice [5]. However, the present productivity of rice in eastern India is quite low and uncertain because of its dependency on monsoon, climatic abnormalities, and poor management practices [6,7]. Seedbed management is one of the crucial aspectsof rice production [8], most particularly in the winter season as temperature plays a pivotal role in the development of seedlings at the juvenile stage by influencing numerous physiological changesinthe plant body [9].

Temperatures below the critical level haveconsequences of poor germination, stunted growth, low leaf chlorophyll level, and even cause huge seedling mortality [10]. The critical temperatures for rice seed germination and root and shoot development is $10^{\circ} \mathrm{C}, 12$ to $16^{\circ} \mathrm{C}$, and 7 to $16^{\circ} \mathrm{C}$, respectively [11,12]. Globally, more than 15 million ha of rice seedbed is affected by cold injury [13]. In Asia and southeast Asia $\sim 7$ million ha of potential land in rice cultivation remains unplanted due to severe damage of seedlings by low-temperature stress [13]. Moreover, the cultivars that come under the indica subspecies are more prone to damage by low temperature [14]. Additionally, recent climate change has resultedin a greater number of cold wave occurrences (Figure 1) from November to mid-February, when the preparation of the seedbed is undertaken forbororice [13].

Low-temperature stress and foggy weather, along with traditional age-old nursery management, also seem to be major reasons for delayed transplantation of the main field. These result in fewergrowing degree days andless solar radiation, and they shorten the vegetative period with poor tiller formation in the main field [15]. The boro rice may adversely suffer from terminal heat stress and cyclonic storms, generally occurring from March onwards due to delayed transplanting. It has been reported that there has been a drastic decrease in the production of major cereals up to 2020 viz. $11 \%$ for rice [16]. Protection fromlow temperatures is the most important component for winter survival, but also of considerable importance is the capability to withstand combinations of stresses due to cold waves, low light, and variation in diurnal temperature. To defend the rice seedbed from frequent cold waves in the winter season and grow vigorous seedlings inany climatic abnormalities within a short time span, the development of an integrated climateresilient technique would be a welcome strategy, which includes the sowing of healthy pre-germinated seeds, the covering of seedbeds by transparent polythene sheets, and the changing of the fertilization strategy in the seedbed.Transparent polythene coverings act as a greenhouse that controls the fluctuation of diurnal variation and optimizes the internal temperature $[17,18]$, protects moisture evaporation directly from the soil surface, controls weed emergence $[19,20]$, and thus increases the moisture and nutrient use efficiency by seedlings and avoids low-temperature stress [21]. Additionally, the supplementary application of micro-nutrients, especially $\mathrm{Zn}$ and B, improves the statute of rice seedlings; it has been well established that a deficiency of $\mathrm{Zn}$ is most widespread in the region where continuous soil disturbance is carried out for intensive agriculture. This modified package and practices from the existing knowledge pool lower the time span for seedling raising and affect the younger seedlings attributed to vigorous plant growth andbetter tillering habits, yield attributes, and yield of rice as they usually recover from the transplanting shock more quickly, remove soil nutrients efficiently, and resist disease pest infestation better than older seedlings [22,23]. 


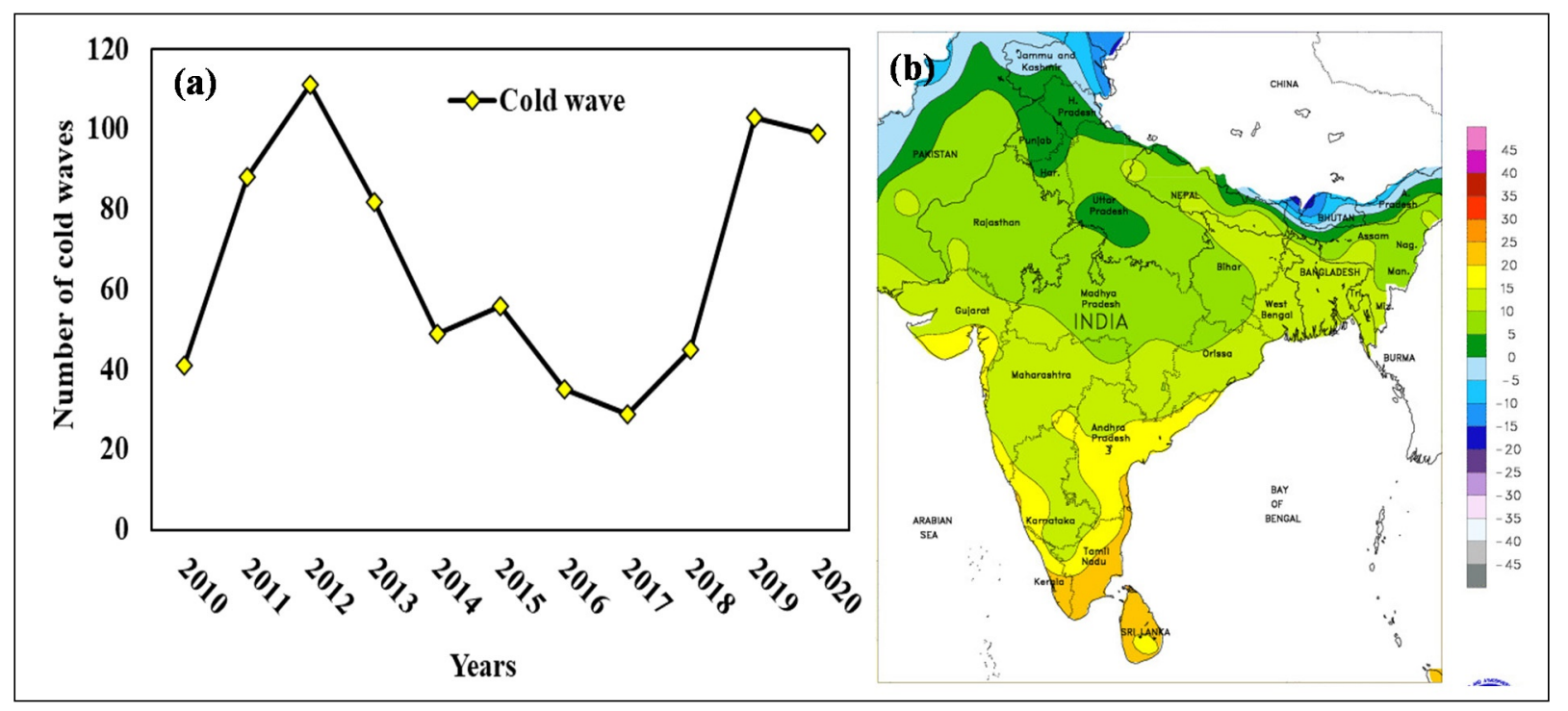

Figure 1. The number of cold waves occurs in the last ten years in India (a) and the areas where rice production is uncertain in recent years (b). Modified from Statista [24].

In earlier studies, it had been well established that the genetic modification or changes in the date of sowing were effective against cold injuries in rice seedlings [13,25], but no previous works have emphasized the economically affordable andshort duration seedbed management strategy by addressing the current weather abnormalities. This study not only highlights the performance of seedlings under polythene coverings in terms of growth, survival rate, and nutritional and biochemical qualities, but also established the seed germination technique more conveniently by developing a germinator within a reasonable price.

\section{Materials and Methods}

\subsection{Experimental Site}

The field trial was carried out at the Central Research Farm of Bidhan Chandra KrishiViswavidyalaya, Gayeshpur, West Bengal, India $\left(23^{\circ} 8^{\prime} \mathrm{N}\right.$ latitude and $88^{\circ} \mathrm{E}$ longitude, with an average altitude of $9.75 \mathrm{~m}$ above mean sea level) during the winter (December to January) seasons of 2017-2018 (Year 1) and 2018-2019 (Year 2).

\subsection{Climatic Condition}

The climate of the study site was sub-tropical. The variation in temperature, relative humidity, and sunshine hours during the experimental period (December to January) is presented in Figure 2; soil temperature (0-15 cm depth) fluctuated between $24.8-18.2^{\circ} \mathrm{C}$ and 23.4-16. ${ }^{\circ} \mathrm{C}$ in $2017-2018$ and $2018-2019$, respectively. The aerial temperature fluctuations were not ambient for seedling raising and caused seedling morality in farmer's fields at this particular location.

\subsection{Edaphic Condition}

The soil was clay loam in texture with neutral $\mathrm{pH}$. Before commencing the experiment, the status of soil organic carbon andavailable N, P, and K is presented in Table 1. 


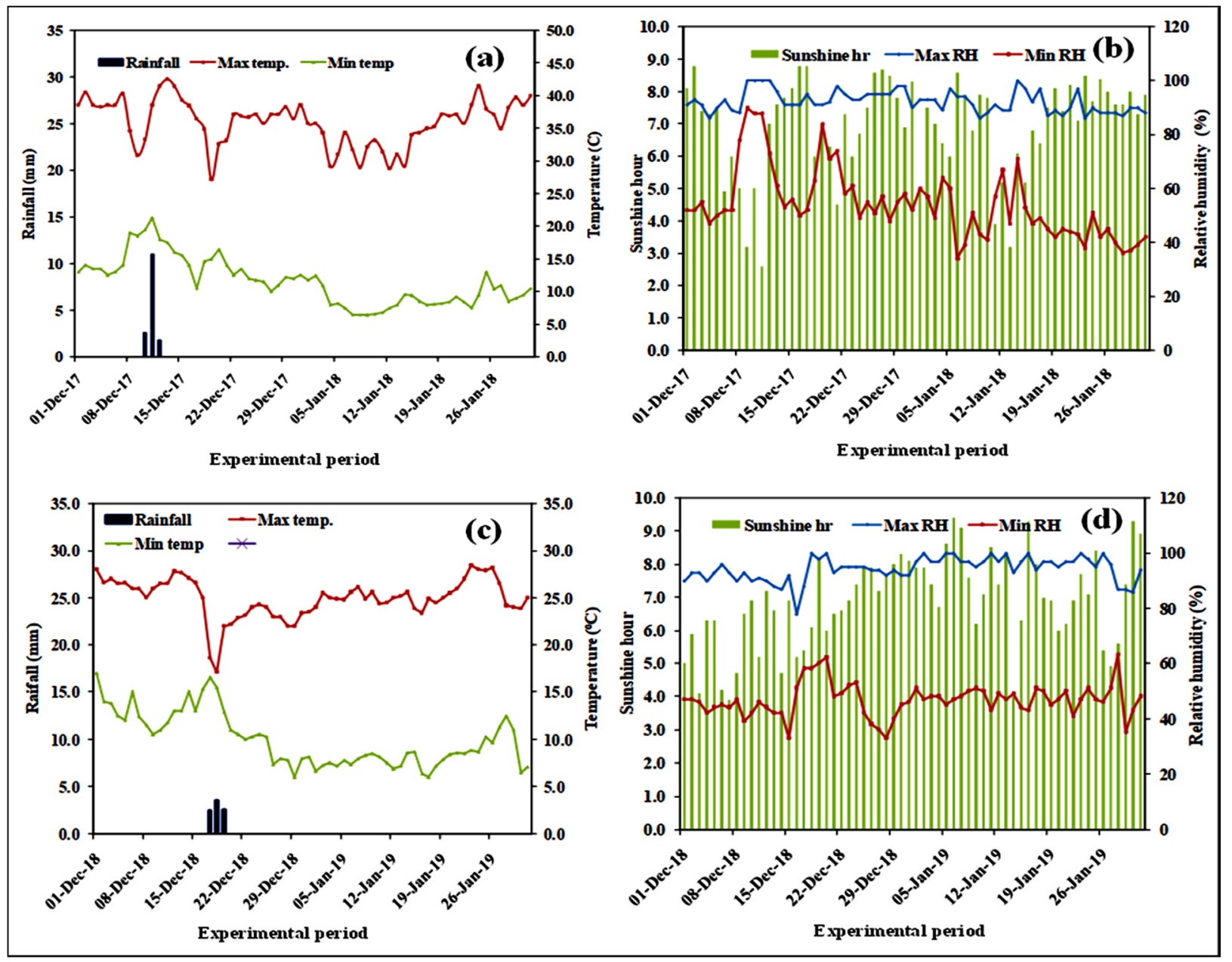

Figure 2. Meteorological observation of rainfall and temperature in 2017-2018 (a), sunshine hours and relative humidity in 2017-2018 (b), rainfall and temperature in 2018-2019 (c), sunshine hours and relative humidity in 2018-2019 (d).

Table 1. Soil (0-30 cm depth) physical and chemical properties before commencing the experiment.

\begin{tabular}{|c|c|c|c|c|}
\hline \multirow{2}{*}{ Particulars } & \multirow{2}{*}{ Unit } & \multicolumn{2}{|c|}{ Value } & \multirow{2}{*}{ Method } \\
\hline & & 2017-2018 & 2018-2019 & \\
\hline \multicolumn{5}{|c|}{ Physical properties } \\
\hline Sand & $(\%)$ & 35.2 & 36.2 & \\
\hline Silt & $(\%)$ & 26.4 & 28.2 & Hydrometer method [26] \\
\hline Clay & $(\%)$ & 36.4 & 38.0 & \\
\hline Soil texture & - & $\begin{array}{c}\text { Clay-loam } \\
\text { (Illite dominant) }\end{array}$ & $\begin{array}{c}\text { Clay-loam } \\
\text { (Illite dominant) }\end{array}$ & Textural triangular method Brady and Weil [27] \\
\hline \multicolumn{5}{|c|}{ Chemical properties } \\
\hline $\mathrm{pH}$ & - & 7.61 & 7.26 & $\mu$-processor-based pH-EC-Ion meter [28] \\
\hline Organic C & $(\%)$ & 0.58 & 0.51 & {$[29]$} \\
\hline Available N & $\mathrm{kg} \mathrm{ha}^{-1}$ & 216.0 & 195.3 & Hot alkaline $\mathrm{KMnO}_{4}$ Method [30] \\
\hline Available P & $\mathrm{kg} \mathrm{ha}^{-1}$ & 37.2 & 48.6 & $0.5 \mathrm{M} \mathrm{NaHCO}_{3}$ extract [31] \\
\hline Available K & $\mathrm{kg} \mathrm{ha}^{-1}$ & 176.4 & 184.3 & Neutral $\mathrm{N} \mathrm{NH}_{4} \mathrm{OAc}$ extract [32] \\
\hline
\end{tabular}




\subsection{Details of the Experiment}

\subsubsection{Treatment Details and Statistical Design}

The research was carried out in ten experimental units and deployed the independentsample $t$-test to compare the performance of seedlings between two seedbed management practices viz. conventional seedbed and the modified, improved seedbed. The improved seedbed management was an integrated approach that consisted of the sowing of pregerminated seeds from the newly developed germinator, supplementary application of micronutrients, and covering the seedbed with transparent polythene. The size of each unit plot was $5 \mathrm{~m} \times 2 \mathrm{~m}$ witha $30 \mathrm{~cm}$-wide channel in between the plots. The seeds of medium duration rice variety Shatabdi (IET 4786) were broadcasted. The ten observations were taken from each treatment for statistical analysis.

\subsubsection{Germination of Seeds}

The farmer's practice was followed in the conventionalmethod where the watersoaked seeds were kept into the straw or gunny bag to raise the internal temperature and germinate the seeds within 3-4 days. The optimum temperature for most of the rice seed germination is between 15 and $30{ }^{\circ} \mathrm{C}$, and the maximum temperature is between 30 to $40{ }^{\circ} \mathrm{C}$ [9]. In an improved method, a simple and cost-effective seed germinator was developed by using the aforesaid theory where boiled water $\left(100^{\circ} \mathrm{C}\right)$ and normal water $\left(20-22{ }^{\circ} \mathrm{C}\right)$ were mixed in a $1: 2.5$ ratio to maintain the water temperature at $40{ }^{\circ} \mathrm{C}$. The process of seed germination is available in Figure 3.

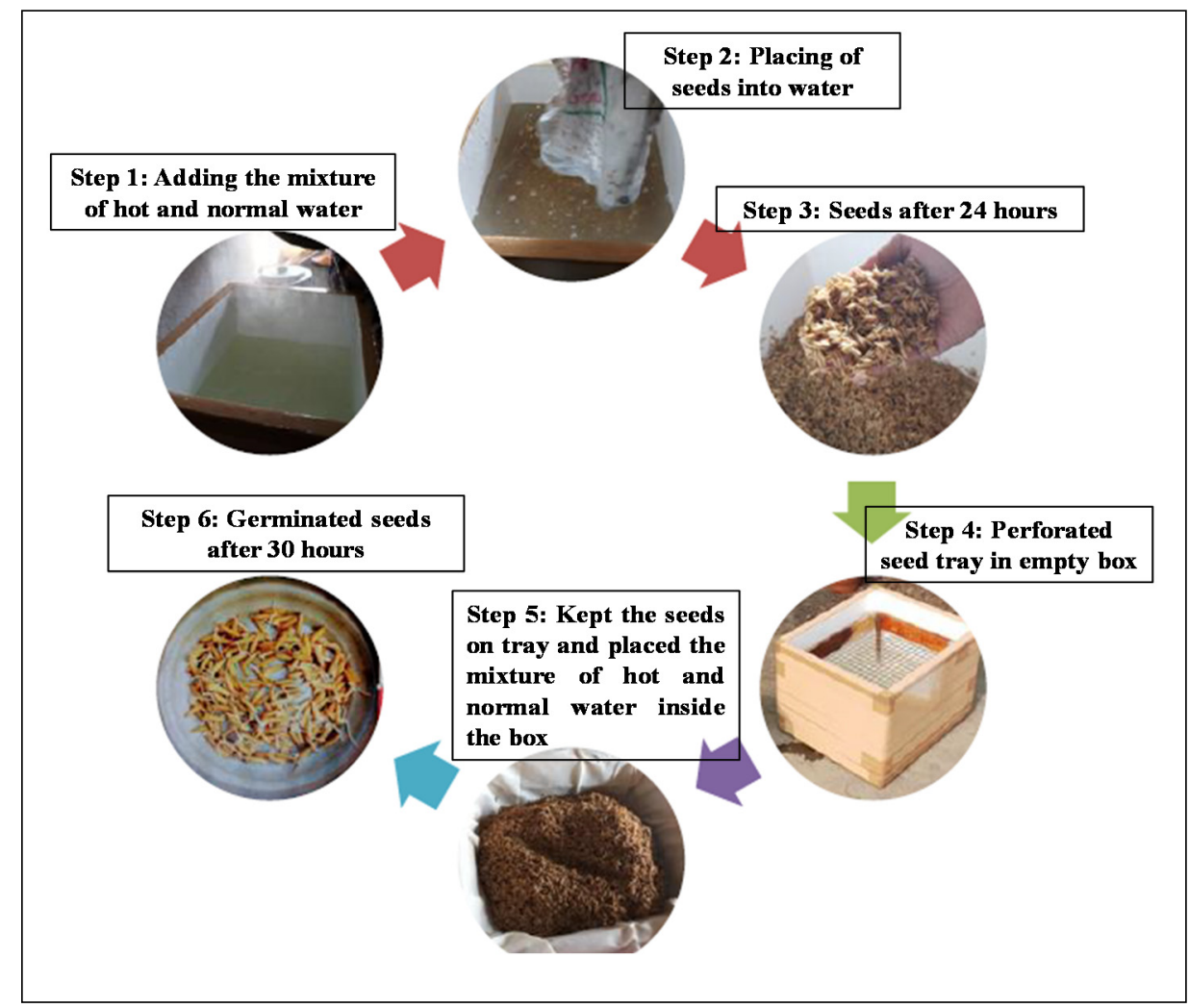

Figure 3. Flow chart of rice seed germination by using a newly invented germinator.

Initially, (i) rice seeds were dipped into salt water (180 g salt lit ${ }^{-1}$ of water) to remove the chaffy grain. Then, the filled grains were collected and thoroughly washed by freshwater; (ii) a total of 12 lit of normal water was mixed with 5 lit of hot water in a blank thermocool box (20 lit capacity).Washed seeds were placed into this box and germinator was closed for $24 \mathrm{~h}$; (iii) after $24 \mathrm{~h}$ the seeds were kept out and water was drained out from the germinator. After that, a seed tray was covered with a thin cotton cloth and placed 
into the germinator. Seeds were spread onto it and covered by a wet jute gunny bag; (iv) a mixture of 10 lit normal water with 5 lit hot water was fed into the germinator through a pipe immediately, but the seeds should not be touched bywater, sothe germinator was closed to be airtight; (v) after 30-35 h, pre-germinated rice seeds were taken from the germinator and were ready for sowing.

\subsubsection{Preparation of Nursery Bed \\ Conventional Nursery Bed}

The land was ploughed ( 3 times) in $4-5 \mathrm{~cm}$ standing water, followed by at least one laddering to make a well-puddled seedbed. FYM was thoroughly mixed at $2.5 \mathrm{t}$ per $1000 \mathrm{~m}^{2}$ before ten days of final land preparation. A uniform dose of $\mathrm{N}: \mathrm{P}_{2} \mathrm{O}_{5}: \mathrm{K}_{2} \mathrm{O}$ at 2.5:5:2:2.5 per 0.1 ha was applied at the time of land preparation.Pre-germinated seeds were sown carefully in seedbeds with a seed rate of $50 \mathrm{~kg}$ per $1000 \mathrm{~m}^{2}$ area for 1 ha main field. All the recommended packages and practices were followed for conventional nursery bed [8]. Weeds were removed at 10 DAS (days after sowing) to keep the seedbed weed-free. During the first 7 days, the seedbeds were kept under saturation conditions by allowing water in the irrigation channel only, and after that $2-3 \mathrm{~cm}$ water was maintained, which was gradually increased up to $5 \mathrm{~cm}$ on the date of uprooting of seedlings. In a conventional seedbed, the seedlings were ready for transplantation at 45 DAS.

\section{Improved Nursery Bed}

In the improved seedbed, a similar land preparation technique was followed as for theconventional seedbed. FYM was thoroughly mixed at $2.5 \mathrm{t}$ per $1000 \mathrm{~m}^{2}$ before ten days of final land preparation. A uniform dose of $\mathrm{N}: \mathrm{P}_{2} \mathrm{O}_{5}: \mathrm{K}_{2} \mathrm{O}: \mathrm{Zn}: \mathrm{B}$ at 2.5:5:2:2.5:0.1 kg per 0.1 ha was applied at the time of land preparation. Pre-germinated seeds from the germinator were sown in seedbeds with a seed rate of $50 \mathrm{~kg}$ per 0.1 ha area for a 1 ha main field. Then, the seedbeds were covered with a thin transparent polythene sheet ( $1.5 \mathrm{ft}$ height from bed) and the ages were buried in soil on both sides up to 15 DAS. At 15 DAS, topdressing with $\mathrm{N}$ witha similar dose of basal was operated. After that, the seedbed was opened during the daytime and covered inthe afternoon to avoid the cold injury of seedlings at night up to 20 DAS. Then, the seedbed was exposed to acclimatize to the natural weather, and after 5 days (25 days-old seedlings), the seedlings were ready for transplantation. Up to one week after commencing the sowing, stagnant water was maintained only in the irrigation channels to keep the nursery beds under saturated conditions, and then a thin layer of standing water was maintained in the seedbed throughout the whole period.

\subsubsection{Measurement and Analytical Procedure Biometric Observations}

Seedling height, root length, dry matter accumulation, and leaf and tiller count were recorded from the ten randomly selected seedlings in each plot at 7, 14, and 21 days after sowing (DAS). Seedlings were uprooted carefully, and their height was measured from the base of the seedling to the tip of the leaf. The root length was recorded between the collar region and the tip of the root by using a meter scale. To record dry matter production, the uprooted seedlings were washed thoroughly and sun-dried, and then the samples were divided into leaf and root categories, which were oven-dried $\left(70^{\circ} \mathrm{C}\right)$. The seedling growth rate was calculated by using the equation of crop growth rate [33]:

$$
\mathrm{SGR}=\frac{\mathrm{W}_{2}-\mathrm{W}_{1}}{\mathrm{~T}_{2}-\mathrm{T}_{1}} \times \frac{1}{\mathrm{~A}} \mathrm{~g} / \mathrm{m}^{2} / \text { day }
$$

where SGR indicates the seedling growth rate, $\mathrm{W}_{2}$ indicates the final dry weight at time $\mathrm{T}_{2}$ and $W_{1}$ indicatesthe initial dry weights of plant material at times $T_{1}$, and $A$ indicates the ground area $\left(\mathrm{m}^{2}\right)$.

The division of the root length of ten randomly selected seedlings with the shoot length (seedling height) of respective seedlings was taken as root:shoot ratio. In each 
seedbed, ten random seedlings were selected and marked for counting the tiller number at 7-day intervals commencing from sowing till transplanting. The average of ten seedling's tillers was considered as the final tiller count. The number of leaves was counted from the seedlings which were marked for tiller count. The seedling emergence percentage was calculated at 7 DAS by placing the five numberd quadrates $\left(0.5 \times 0.5 \mathrm{~m}^{2}\right)$ randomly in each seedbed; how manyseedlings emerged from placed seeds were counted and the average from the five quadrates was then converted into a percentage by following the following formula [34]:

$$
\mathrm{E}(\%)=\frac{\mathrm{S}_{\mathrm{e}}}{\mathrm{S}_{\mathrm{t}}} \times 100
$$

where $\mathrm{E}$ indicates the seedling emergence, $\mathrm{S}_{\mathrm{e}}$ indicates the emerged seedlings atthe time of measurement, and $S_{t}$ indicatesthe total number of seeds sown in the nursery bed.

The seedling survival percentage was calculated before a day of transplantation from the aforesaid five quadrates $\left(0.5 \times 0.5 \mathrm{~m}^{2}\right)$ by the following formula [34]:

$$
\mathrm{S}(\%)=\frac{\mathrm{S}_{\mathrm{u}}}{\mathrm{S}_{\mathrm{e}}} \times 100
$$

where $S$ indicates the survival of seedlings, $S_{u}$ indicatesthe number of seedlings at the time of uprooting, and $\mathrm{S}_{\mathrm{e}}$ indicates the emerged seedlings.

The final seedling count at the time of uprooting was taken from the five random quadrates $\left(0.5 \times 0.5 \mathrm{~m}^{2}\right)$ and the average values were converted into an $\mathrm{m}^{2}$ basis.

\section{Temperature and Relative Humidity}

Soil temperature was recorded by using soil thermometers (Luster Leaf 1625, Beijing, China) inserted at $15 \mathrm{~cm}$ depth at 10 AM, 2 PM, and 4 PM during 7, 14, and 21 DAS. Relative humidity was measured by Assmannpsychrometer(V-Tech, Coimbatore, India) from seedbed at similar time intervals.

\section{Nutrient Assessment}

The oven-dried $\left(60 \pm 5{ }^{\circ} \mathrm{C}\right)$ seedlings (collected before transplanting) were sieved through a $0.5 \mathrm{mmmesh}$ sieve to determine the nutrient $(\mathrm{N}, \mathrm{P}$, and $\mathrm{K})$ concentrations. The modified micro-Kjeldahl method was used to measure $\mathrm{N}$ recoveries. To determine the $\mathrm{P}$ and $\mathrm{K}$ concentration, the digestion of samples with a tri-acid $\left(\mathrm{HNO}_{3}: \mathrm{H}_{2} \mathrm{SO}_{4}: \mathrm{HClO}_{4}=10: 1: 4\right)$ mixture was carried out and the recovery of $\mathrm{P}$ and $\mathrm{K}$ were measured by using a spectrophotometer or flame photometer, respectively [35].

\section{Chlorophyll Content}

A SPAD-502 Chlorophyll meter (Konica Minolta, Tokyo, Japan) was used to determine the chlorophyll content of seedlings [9]. The physiologically active seedlings' leaveswere put into the sensor of the SPAD meter and the value was recorded. The average of the ten observations was taken as the SPAD reading.

\section{Cost of Production}

The cost involvement in seedbed management was calculated based on theprevailing market price of the inputs. The multiplication of the market price of inputs (machinery, seeds, water, labour, polythene, etc.) with their required amount was taken as the cost of production.

\section{Energy Budgeting}

Energy budgetingwascarried out by considering theinputs, their quantity, and the machinery/manual labour usedwith their duration. To estimate the energy input of eachtreatment, a complete record of all inputs (seeds, fertilizers, fuel, human labour, machinery power, polythene covering, etc.) was systematically calculated. Energy use during 
nurserybed preparationwas convertedfrom physical units to energy units throughmultiplication with the conversion coefficients (Table A1).

\section{Statistical Analysis}

An independent $t$-test was used to analyze the significant difference $(0.05 \%$ or $0.01 \%$ probability level) among year-wise data through the STAR (Statistical Tool for Agricultural Research, International Rice Research Institute, Los Baños, Philippines) [36].

\section{Results}

\subsection{Micro-Climatic Condition}

The soil temperature was measured at a $15 \mathrm{~cm}$ depth and, irrespective of time of day and observation intervals, the higher temperature was recorded from a polythene-protected seedbed than an unprotected, conventional nursery bed (Figure 4). A similar trend of observation was recorded in the case of relative humidity measurement during both the years of experimentation (Figure 5).
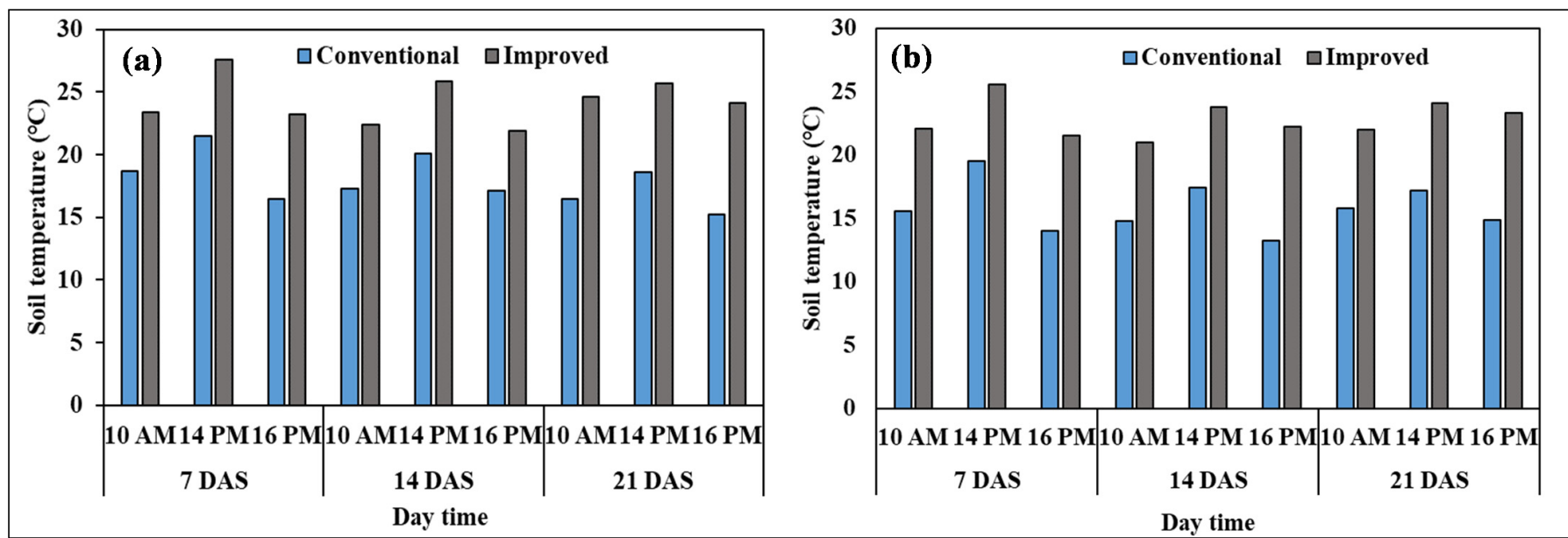

Figure 4. Effect of seedbed management practices on soil temperature at different times of day during 2017-2018 (a) and 2018-2019 (b) at different growth stages.
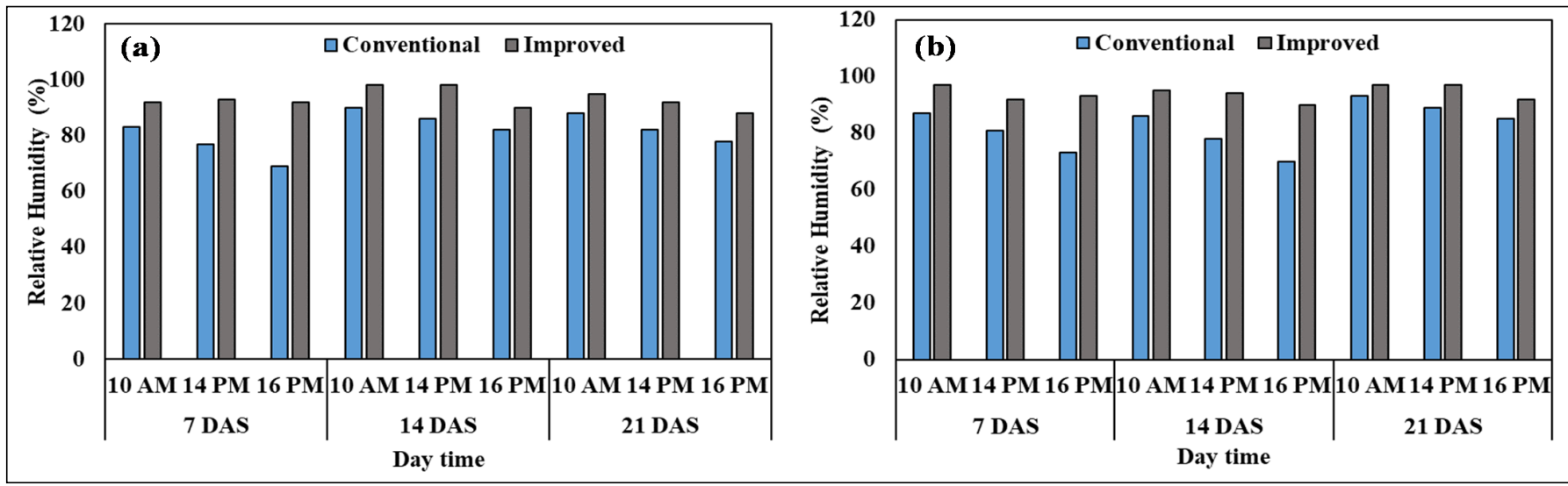

Figure 5. Effect of seedbed management practices on relative humidity at different times of day during 2017-2018 (a) and 2018-2019 (b) at different growth stages. 


\subsection{Growth Attributes}

Higher seedling emergence ( 90 and $91 \%$ in $\mathrm{Y} 1$ and $\mathrm{Y} 2$, respectively) from sowed seeds was registered from the protected seedbed, while conventional seedbed resulted in $71 \%$ and $66 \%$ seedling emergence from given seeds in $\mathrm{Y} 1$ and $\mathrm{Y} 2$, respectively (Table 2).

Table 2. Effect of seedbed management practices on emergence, height, and biomass accumulation of boro rice seedlings during 2017-2018 and 2018-2019.

\begin{tabular}{|c|c|c|c|c|c|c|c|c|c|c|c|c|c|c|}
\hline \multirow{3}{*}{ Treatment Details } & \multicolumn{2}{|c|}{$\begin{array}{c}\text { Seedling Emergence } \\
(\%)\end{array}$} & \multicolumn{6}{|c|}{ Seedling Height $(\mathrm{cm})$} & \multicolumn{6}{|c|}{ Above-Ground Biomass (g Seedling ${ }^{-1}$ ) } \\
\hline & \multirow{2}{*}{ Y1 } & \multirow{2}{*}{ Y2 } & \multicolumn{2}{|c|}{7 DAS } & \multicolumn{2}{|c|}{14 DAS } & \multicolumn{2}{|c|}{21 DAS } & \multicolumn{2}{|c|}{7 DAS } & \multicolumn{2}{|c|}{14 DAS } & \multicolumn{2}{|c|}{21 DAS } \\
\hline & & & Y1 & Y2 & Y1 & Y2 & Y1 & Y2 & Y1 & Y2 & Y1 & Y2 & Y1 & Y2 \\
\hline Conventional & 71.00 & 66.00 & 1.10 & 1.53 & 3.70 & 2.97 & 5.93 & 7.16 & 0.03 & 0.04 & 0.73 & 0.85 & 1.85 & 2.72 \\
\hline Improved & 90.00 & 91.00 & 2.80 & 3.94 & 8.00 & 9.67 & 13.33 & 14.60 & 0.06 & 0.08 & 2.19 & 2.88 & 6.04 & 7.14 \\
\hline $\mathrm{SEm} \pm$ & 2.38 & 3.06 & 0.19 & 0.41 & 0.65 & 0.34 & 0.62 & 0.35 & 0.01 & 0.01 & 0.19 & 0.23 & 0.33 & 0.43 \\
\hline $\operatorname{LSD}(p \leq 0.05)$ & $* *$ & $* *$ & $* *$ & $* *$ & $* *$ & $* *$ & $* *$ & $* *$ & $*$ & $* *$ & $* *$ & $* *$ & $* *$ & $* *$ \\
\hline
\end{tabular}

DAS, days after sowing; Y1, Year 1; Y2, Year 2; LSD, least significant difference; ${ }^{* *}$ significant at $p \leq 0.01 ;{ }^{*}$ significant at $p \leq 0.05$.

A significant response was observed from the improved method of seedbed preparation over conventional techniques towards different growth attributes of boro rice seedlings. The seedling height gradually increased with age, and a significantly $(p \leq 0.01)$ higher height was accounted for by improved seedlings irrespective of growth stages and years of experimentation (Table 2). At 21 DAS, the polythene-protected seedbed (improved) resulted in $13.33 \mathrm{~cm}$ and $14.60 \mathrm{~cm}$ seedling height in $\mathrm{Y} 1$ and $\mathrm{Y} 2$, respectively, while a $5.93 \mathrm{~cm}$ and $7.16 \mathrm{~cm}$ height was obtained from the conventional seedbed. Similar to plant height, greater biomass accumulation was recorded from the seedlings raised under the improved nursery bed (Table 2). Almost $226 \%$ and $179 \%$ higher aboveground biomass was observed from improved seedlings as compared to conventional by 21 DAS. A similar table denoted that initially, the differences in above-ground biomass between improved and conventional were minimum; however, it was increased with increasing time span.

At the early stage, the root dry weight non-significantly varied among the treatments (at 7 DAS of Y1), but it differed significantly ( $p \leq 0.01$ ) afterward (Table 3). Root length was measured as significantly $(p \leq 0.01$ and/or $p \leq 0.05)$ higher from the polythene-protected seedbed as compared to the conventional nursery bed except at 7 DAS of Y2. The root length of rice seedlings was measured as $9.03 \mathrm{~mm}, 14.11 \mathrm{~mm}$, and $22 \mathrm{~mm}$ during 7, 14, and 21 DAS of the firstyear, respectively from the conventional seedbed, whereas $11.12 \mathrm{~mm}$, $39.78 \mathrm{~mm}$, and $59.56 \mathrm{~mm}$ were measured from the improved seedbed at similar periods of observation (Table 3).

Table 3. Effect of seedbed management practices on root dry weight, root length, and root: shoot ratio of boro rice seedling during 2017-2018 and 2018-2019.

\begin{tabular}{|c|c|c|c|c|c|c|c|c|c|c|c|c|c|c|c|c|c|c|}
\hline \multirow{3}{*}{ Treatments } & \multicolumn{6}{|c|}{ Root Dry Weight (g Seedling ${ }^{-1}$ ) } & \multicolumn{6}{|c|}{ Root Length (mm Seedlings ${ }^{-1}$ ) } & \multicolumn{6}{|c|}{ Root: Shoot Ratio } \\
\hline & \multicolumn{2}{|c|}{7 DAS } & \multicolumn{2}{|c|}{14 DAS } & \multicolumn{2}{|c|}{21 DAS } & \multicolumn{2}{|c|}{7 DAS } & \multicolumn{2}{|c|}{14 DAS } & \multicolumn{2}{|c|}{21 DAS } & \multicolumn{2}{|c|}{7 DAS } & \multicolumn{2}{|c|}{14 DAS } & \multicolumn{2}{|c|}{21 DAS } \\
\hline & Y1 & Y2 & Y1 & Y2 & Y1 & Y2 & Y1 & Y2 & Y1 & Y2 & Y1 & Y2 & Y1 & Y2 & Y1 & Y2 & Y1 & $\mathrm{Y} 2$ \\
\hline Conventional & 0.01 & 0.02 & 0.16 & 0.25 & 0.82 & 0.97 & 9.0 & 9.0 & 14.1 & 15.3 & 22.0 & 20.0 & 0.82 & 0.59 & 0.38 & 0.52 & 0.37 & 0.28 \\
\hline Improved & 0.04 & 0.05 & 0.77 & 0.81 & 1.90 & 2.09 & 11.2 & 11.0 & 39.8 & 40.3 & 59.5 & 62.3 & 0.40 & 0.28 & 0.50 & 0.42 & 0.45 & 0.43 \\
\hline $\mathrm{SEm} \pm$ & 0.01 & 0.01 & 0.09 & 0.12 & 0.17 & 0.09 & 0.7 & 0.8 & 0.9 & 1.2 & 1.9 & 2.4 & - & - & & - & - & - \\
\hline $\operatorname{LSD}(p \leq 0.05)$ & ns & * & $* *$ & ** & $* *$ & $* *$ & * & ns & $* *$ & $* *$ & $* *$ & $* *$ & - & - & - & - & - & - \\
\hline
\end{tabular}

DAS, days after sowing; Y1, Year 1; Y2, Year 2; LSD, least significant difference; ${ }^{* *}$ significant at $p \leq 0.01 ;{ }^{*}$ significant at $p \leq 0.05$; ns, non-significant.

The root length in the second year at a specific time interval was in harmony with the trend inthe first year of experimentation. The data presented in Table 3 denotes that the greater root:shoot ratio was calculated from conventional seedbed at an earlier 
growth phase; however, at a later stage it was maximum in the seedlings from improved nursery bed.

The highest number of tillers from each seedling was foundforthe improved nursery bed at 14 and 21 DAS as compared to the conventional seedbed irrespective of being in the first year orsecond year of experimentation (Table 4). The seedlings raised under a polythene covering took less time forleaf emergence than unprotected conventional seedlings. The data summarized in Table 4 denotes that almost one month was required for thefourthleaf to emerge in conventional seedlings, while three weeks were neededby the improved seedlings forfourthleaf emergence.

Table 4. Effect of seedbed management practices on tiller count, days to leaf emergence and leaves count of boro rice seedling during 2017-2018 and 2018-2019.

\begin{tabular}{|c|c|c|c|c|c|c|c|c|c|c|c|c|c|c|c|c|c|c|}
\hline \multirow{3}{*}{$\begin{array}{l}\text { Treatment } \\
\text { Details }\end{array}$} & \multicolumn{4}{|c|}{$\begin{array}{c}\text { Tillers } \\
\text { (no. Seedling }^{-1} \text { ) }\end{array}$} & \multicolumn{8}{|c|}{ Days to Leaf Emergence } & \multicolumn{6}{|c|}{ Leaves (no. Seedling ${ }^{-1}$ ) } \\
\hline & \multicolumn{2}{|c|}{14 DAS } & \multicolumn{2}{|c|}{21 DAS } & \multicolumn{2}{|c|}{ 1st Leaf } & \multicolumn{2}{|c|}{ 2nd Leaf } & \multicolumn{2}{|c|}{ 3rd Leaf } & \multicolumn{2}{|c|}{ 4th Leaf } & \multicolumn{2}{|c|}{7 DAS } & \multicolumn{2}{|c|}{14 DAS } & \multicolumn{2}{|c|}{21 DAS } \\
\hline & Y1 & Y2 & Y1 & $\mathrm{Y} 2$ & Y1 & $\mathrm{Y} 2$ & Y1 & $\mathrm{Y} 2$ & Y1 & $\mathrm{Y} 2$ & Y1 & $\mathrm{Y} 2$ & Y1 & $\mathrm{Y} 2$ & Y1 & $\mathrm{Y} 2$ & Y1 & $\mathrm{Y} 2$ \\
\hline Conventional & 0.80 & 0.65 & 1.15 & 1.21 & 9 & 10 & 15 & 19 & 21 & 25 & 30 & 33 & 1.10 & 1.93 & 2.37 & 2.97 & 3.02 & 1.10 \\
\hline Improved & 1.13 & 1.24 & 1.53 & 1.68 & 5 & 5 & 8 & 9 & 16 & 15 & 22 & 21 & 1.80 & 2.93 & 3.00 & 3.97 & 3.73 & 1.80 \\
\hline $\mathrm{SEm} \pm$ & 0.07 & 0.11 & 0.04 & 0.09 & 0.94 & 0.67 & 0.82 & 0.88 & 1.05 & 0.75 & 0.67 & 1.20 & 0.18 & 0.09 & 0.19 & 0.09 & 0.16 & 0.18 \\
\hline $\operatorname{LSD}(p \leq 0.05)$ & $* *$ & $* *$ & $* *$ & $* *$ & $* *$ & $* *$ & ** & $* *$ & $* *$ & $* *$ & $* *$ & $* *$ & $* *$ & $* *$ & $* *$ & $* *$ & $* *$ & $* *$ \\
\hline
\end{tabular}

DAS, days after sowing; Y1, Year 1; Y2, Year 2; LSD, least significant difference; ${ }^{* *}$ significant at $p \leq 0.01$.

Seedling growth rate significantly $(p \leq 0.05)$ increased at an increasing rate forthe improved seedbed from sowing to 21 DAS during 2017-2018; however, the growth rate increased with a decreasing rate in between 14-21 DAS in conventional seedlings (Figure 6). During the second year of experimentation, seedlings from both treatments showed an increasing trend of growth rate from sowing to21 DAS, though improved seedlings always grew faster than conventional seedlings.

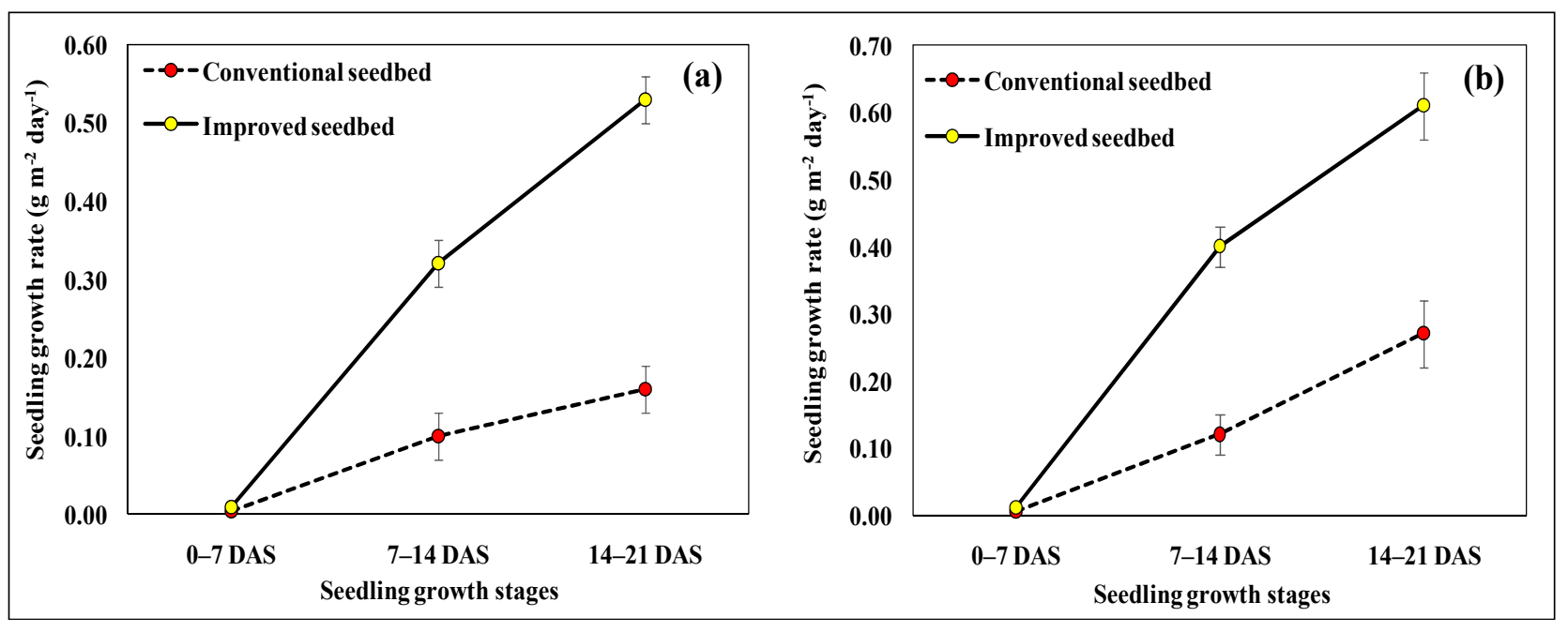

Figure 6. Effect of seedbed management practices on the growth rate of boro rice seedlings during 2017-2018 (a) and 2018-2019 (b) at different growth stages.

A greater survival percentage ( 87.33 and $85.67 \%$ during the first year and second year of experimentation) from sowing to before transplanting was observed in the improved nursery bed over the conventional seedbed (71.67 and $60.33 \%$ in the consecutive two years) (Table 5). The final counting of seedlings from a unit area $\left(\mathrm{m}^{2}\right)$ at the time of uprooting also followed the same trend as seedling emergence and survival rate. The seedlings were 
counted at 675 and 656 per $\mathrm{m}^{2}$ from the improved nursery bed that significantly $(p \leq 0.01)$ differed from the number of seedlings (561 and 527 in Y1 and Y2, respectively) counted from the conventional nursery bed (Table 5). The production of healthy seedlings from improved plots and the comparison between the two types of seedlings are illustrated in Figure 7.

Table 5. Effect of seedbed management practices on survival rate and seedling count of boro rice during 2017-2018 and 2018-2019.

\begin{tabular}{ccccc}
\hline \multirow{2}{*}{ Treatment Details } & \multicolumn{2}{c}{ Survival\% } & \multicolumn{2}{c}{ Seedling $\mathbf{~ m}^{-\mathbf{2}}$} \\
\cline { 2 - 5 } & Y1 & Y2 & Y1 & Y2 \\
\hline Conventional & 71.67 & 60.33 & 561 & 527 \\
Improved & 87.33 & 85.67 & 675 & 656 \\
\hline SEm \pm & 2.49 & 2.21 & 8.21 & 14.46 \\
\hline LSD $(p \leq 0.05)$ & $* *$ & $* *$ & $* *$ & $* *$
\end{tabular}

DAS, days after sowing; Y1, Year 1; Y2, Year 2; LSD, least significant difference; ** Significant at $p \leq 0.01$.

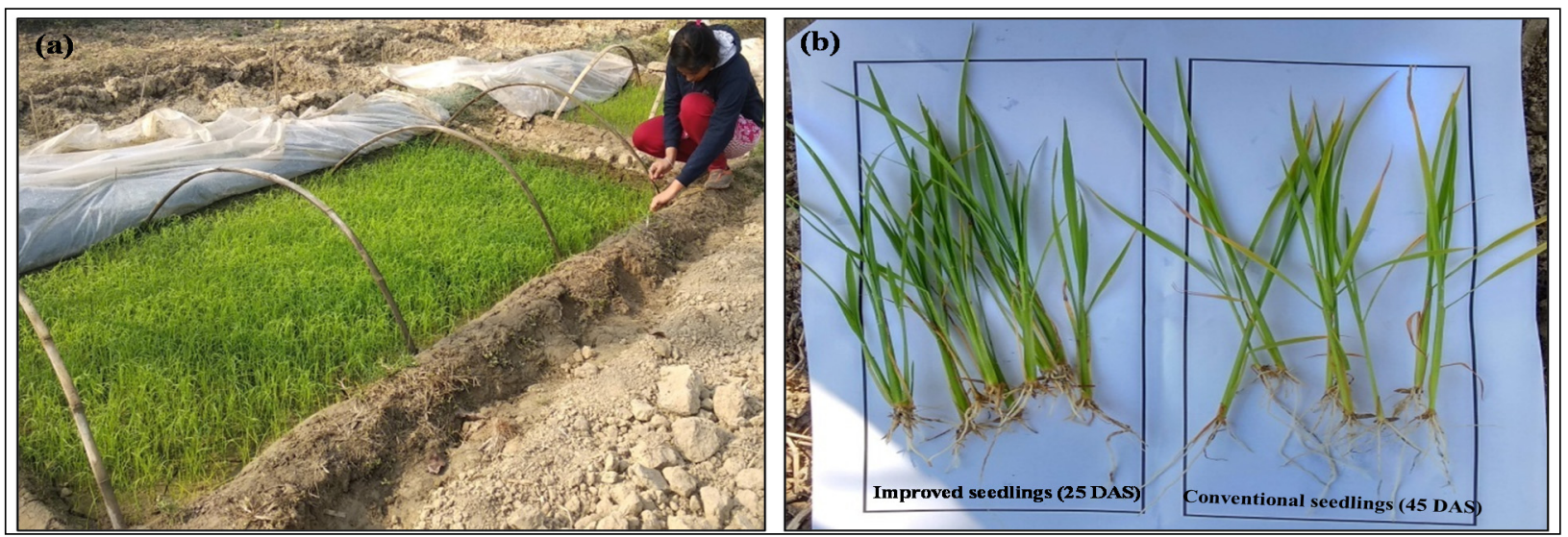

Figure 7. Improved nursery bed (a) and the comparison between improved seedlings and conventional seedlings (b) at the time of uprooting.

\subsection{Nutrient Uptake}

The data presented in Table 6 indicate that higher nutrient $(\mathrm{N}, \mathrm{P}$, and $\mathrm{K})$ accumulation was accounted for more by improved seedlings than conventional. Significantly $(p \leq 0.05)$ greater $\mathrm{N}(2.07 \%), \mathrm{P}(0.48 \%)$, and $\mathrm{K}(3.04 \%)$ concentrationsresulted from improved seedlings, while $1.81 \%, 0.38 \%$, and $2.50 \% \mathrm{~N}, \mathrm{P}$, and $\mathrm{K}$ accumulation was recorded from conventional seedlings during $\mathrm{Y} 1$ of experimentation. A similar trend was observed in the second year; however, the P accumulation did not differ significantly in the second year (Table 6).

Table 6. Effect of seedbed management practices on N, P, and K content in boro rice seedlings during 2017-2018 and 2018-2019.

\begin{tabular}{ccccccc}
\hline \multirow{2}{*}{ Treatment Details } & \multicolumn{2}{c}{ N (\%) } & \multicolumn{2}{c}{$\mathbf{P ~ ( \% )}$} & \multicolumn{2}{c}{ K (\%) } \\
\cline { 2 - 7 } & $\mathbf{Y 1}$ & $\mathbf{Y 2}$ & $\mathbf{Y 1}$ & $\mathbf{Y 2}$ & $\mathbf{Y 1}$ & $\mathbf{Y 2}$ \\
\hline Conventional & 1.81 & 1.78 & 0.38 & 0.36 & 2.50 & 2.58 \\
Improved & 2.07 & 2.07 & 0.48 & 0.41 & 3.04 & 2.88 \\
\hline SEm \pm & 0.07 & 0.08 & 0.02 & 0.05 & 0.10 & 0.06 \\
\hline LSD $(p \leq 0.05)$ & $*$ & $* *$ & $*$ & $n s$ & $*$ & $* *$
\end{tabular}

$\overline{\mathrm{DAS}}$, days after sowing; Y1, Year 1; Y2, Year 2;LSD, least significant difference; ${ }^{* *}$ Significant at $p \leq 0.01$; * Significant at $p \leq 0.05 ; \mathrm{ns}$, non-significant. 


\subsection{Chlorophyll Content}

Chlorophyll content was constantly enhanced with the age of seedlings. Maximum SPAD values were observed in the fresh leaf of improved seedlings irrespective of the observation period and year of experimentation (Table 7). During 21 DAS, rice seedlings from the polythene-protected seedbed accounted for SPAD values of 2.22 and 2.02 in Y1 and $Y 2$, respectively, which were statistically higher than SPAD values obtained from conventional seedlings (1.71 and 1.63 during two consecutive years).

Table 7. Effect of seedbed management practices on chlorophyll content (SPAD value) in boro rice seedlings during 2017-2018 and 2018-2019.

\begin{tabular}{ccccccc}
\hline \multirow{2}{*}{ Treatment Details } & \multicolumn{2}{c}{ 7 DAS } & \multicolumn{2}{c}{ 14 DAS } & \multicolumn{2}{c}{ 21 DAS } \\
\cline { 2 - 7 } & Y1 & Y2 & Y1 & Y2 & Y1 & Y2 \\
\hline Conventional seedbed & 0.24 & 0.32 & 0.77 & 0.64 & 1.71 & 1.63 \\
Improved seedbed & 0.51 & 0.52 & 1.05 & 1.08 & 2.22 & 2.02 \\
\hline SEm \pm & 0.03 & 0.03 & 0.08 & 0.06 & 0.06 & 0.06 \\
\hline LSD $(p \leq 0.05)$ & $* *$ & $* *$ & $*$ & $* *$ & $* *$ & $* *$
\end{tabular}

DAS, days after sowing; Y1, Year 1; Y2, Year 2; LSD, least significant difference; ${ }^{* *}$ Significant at $p \leq 0.01$; * Significant at $p \leq 0.05$.

\subsection{Input Use}

Higher input involvement in terms of labour and irrigation water was observed in conventional seedbeds rather than the improved nursery (Table 8). A total of 11 working days and four irrigation applications were involved for traditionally growing the seedling, whereas only six working days and two times of irrigation were enough for improved nursery bed.

Table 8. Effect of seedbed management practices on input use, age of transplantation, economics, and energy input in boro rice seedlings during 2017-2018 and 2018-2019.

\begin{tabular}{|c|c|c|c|c|c|c|c|c|c|c|}
\hline \multirow[t]{2}{*}{$\begin{array}{l}\text { Treatment } \\
\text { Details }\end{array}$} & \multicolumn{2}{|c|}{$\begin{array}{l}\text { Labour Requirement } \\
\text { (Working Days) }\end{array}$} & \multicolumn{2}{|c|}{$\begin{array}{c}\text { Irrigation } \\
\text { Application } \\
\text { (h) }\end{array}$} & \multicolumn{2}{|c|}{$\begin{array}{c}\text { Seedling Age for } \\
\text { Transplantation (Days) }\end{array}$} & \multicolumn{2}{|c|}{$\begin{array}{l}\text { Cost Involvement } \\
\left(\text { Rs ha }^{-1}\right)\end{array}$} & \multicolumn{2}{|c|}{$\begin{array}{l}\text { Energy Involvement } \\
\left(\mathrm{MJ} \mathrm{ha}^{-1}\right)\end{array}$} \\
\hline & Y1 & $\mathrm{Y} 2$ & $\mathrm{Y1}$ & $\mathrm{Y} 2$ & Y1 & Y2 & $\mathrm{Y1}$ & $\mathrm{Y} 2$ & Y1 & Y2 \\
\hline Conventional & 11 & 11 & 4 & 4 & 45 & 45 & 5171.12 & 5507.12 & 3391.70 & 3391.70 \\
\hline Improved & 6 & 6 & 2 & 2 & 25 & 25 & 2233.00 & 2425.00 & 2910.38 & 2910.38 \\
\hline
\end{tabular}

Y1, Year 1; Y2, Year 2.

\subsection{Age of Seedling Transplantation}

Traditionally, the conventional seedlings are transplanted at 45-50 DAS during the rabi season; however, seedlings raised under the improved method were ready to transplant in the main field at 25 DAS (Table 8).

\subsection{Cost of Production}

Higher cost involvement (Rs. 5171.12 and 5507.12 per 0.1 ha in $Y 1$ and $Y 2$, respectively) was foundfor seedlings grown under the traditional methodsthan the modified improved method (Rs. 2230.00 and 2425.00 per 0.1 ha in $\mathrm{Y} 1$ and $Y 2$, respectively). There was a more than $50 \%$ cost of cultivation involved in conventional methods as compared to the improved nursery (Table 8).

\subsection{Energy Budgeting}

Maximum input energy was estimated from different farming activities involved in conventional seedbed management than improved. The data summarized in Table 8 show that 2910.38 MG energy was involved in improved nursery bed management for 0.1 ha. 
land, while 3391.70 MG energy was involved in the conventional seedbed. Details of energy partitioning in various farm operations carried out for seedbed management arepresented in Figure 8. A higher seed rate and fertilizer application, a greater amountof human labour, and fossil fuel burning through farm machinery resulted in greater energy being involved in the conventional system.

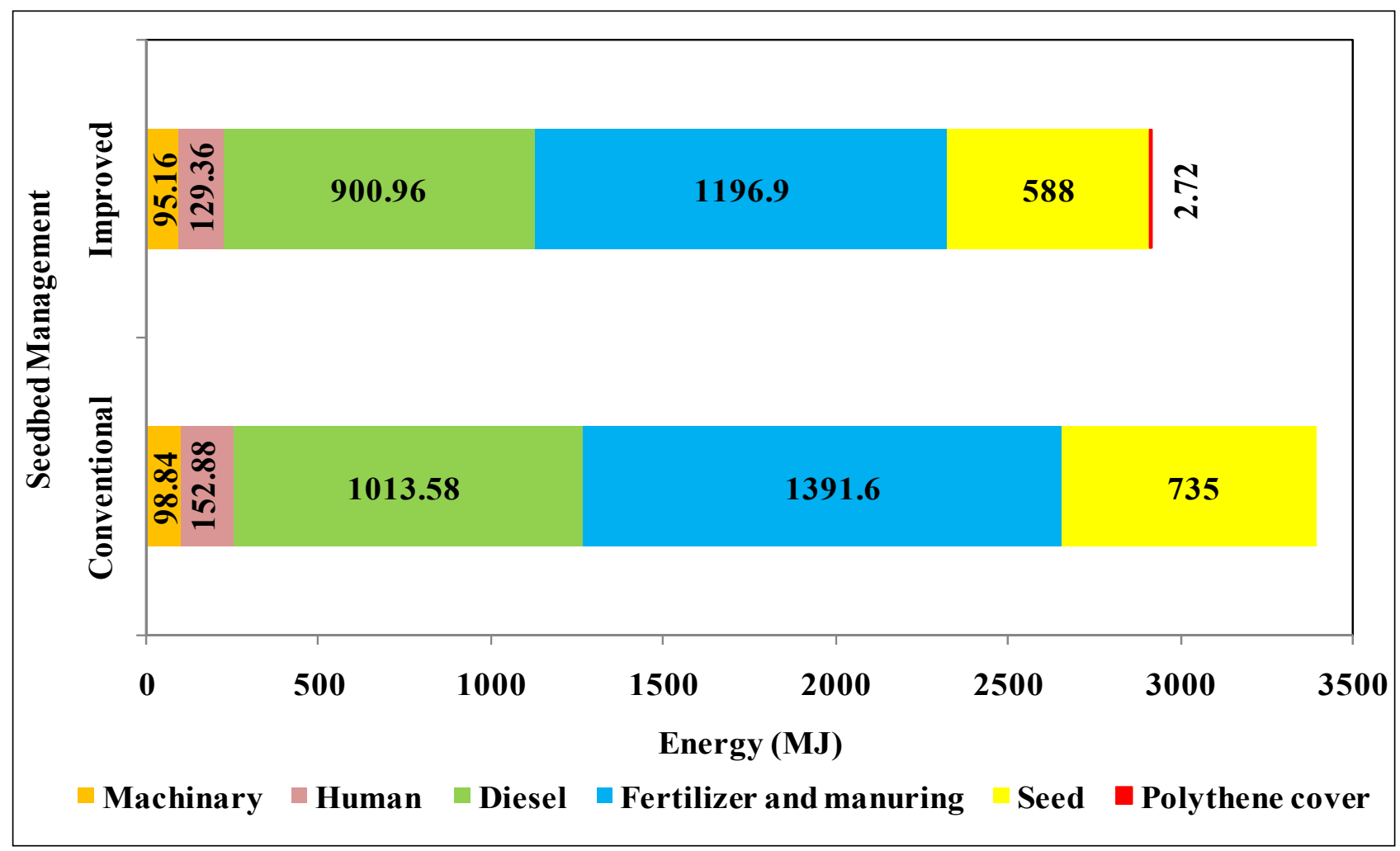

Figure 8. Energy partitioning in various farm operations during boro rice seedbed preparation.

\section{Discussions}

The implementation of a polythene covering maintainedwarm and wet micro-climatic conditions (Figures 4 and 5) in the improved nursery bed as a transparent polythene film allows the short-wave radiation to enter, but prevents it from leaving(greenhouse effect) and inhibits direct evaporation from the soil surface [19].

The aforementionedfavourable micro-climatic conditions resulted in significantly better growth attributes, emergence, and survival rate, along with a greater number of healthy seedlings from the nursery bed, deploying an improved package and practices (polythene protected) as compared to the traditional technique. The findings were in accordance with Azhiri-Sigari et al. [37] and Begum et al. [21], who reported higher shoot length and root length of winter rice seedlings from polythene-covered seedbeds over the traditional method, which might be due to that the higher temperature under the polythene protection enhanced the mitotic activity in cells of the vegetative shoot apex. A reductioninseedling height from $17.4 \mathrm{~cm}$ to $7.9 \mathrm{~cm}$ with low-temperature stress was also observed by Kumar and Reddy [38]. They also concluded that seedlings that were developed from the stated improved technique accumulated a higher plant biomass and saw the lowest mortality rate compared to theconventional technique due tothe creation of a favorable microclimate under the covering. A cold stress reduction in plant height as well as dry matter accumulation are the most common symptoms in rice seedlings [11]. The impact of a low temperature appeared to be more pronounced sequentially inpoor germination and a slower growth rate [10], which was in a line with our findings. Shah et al. [39] observed that the protection of nursery beds with polythene (low tunnel polythene protected nursery) 
produced significantly heavier $(20 \%)$ seedlings than conventionally raised seedlings. These findings are also supported by Rautaray [40]. Tillering habit in rice is highly correlated with light intensity, temperature, and more particularly withmicro-climatic conditions [41]. Moreover, high winds and fog during the cold wave in the winter season also adversely damaged the rice seedlings [13]. Increasing stress results in many anatomical changes in the plant, such as decreases in cell volume, cell division, intercellular spaces, and thickening of the cell wall, which limit the overall plant growth [42]. In this present experiment, favourable soil and aerial temperature, as well as early attainment of the phyllochron stage (fewer than four leaves) from the polythene-protected seedbed, might be a reason for the acceleration of the tiller production than conventional seedbed [23].

Within the range of $20-30{ }^{\circ} \mathrm{C}$, vigorous emergence of plumules and radicles from seeds and their elongation take place, and below $10^{\circ} \mathrm{C}$, this physiological process almost ceases [12]. This hypothesis supports the findings of the present experiment where low seedling emergence $(\sim 70 \%)$ was recorded in theconventional seedbed, and temperature enhancement within polythene coverings resulted in a $~ 90 \%$ emergence rate. It was found that low-temperature stress at the seedling stage lowered the survival percentage [9]. Even in extreme cold, total seedling mortality may occur [25].

The low nutrient uptake capacity by conventionally grown seedlings was observed in the present experiment as compared to polythene-protected seedlings, whichmight be the consequence of a depressed metabolism in rice roots due to a low soil temperature [43]. They also stated that macronutrients (N, P, and $\mathrm{K}$ ) were absorbed efficiently at an average soil temperature of $25^{\circ} \mathrm{C}$, which was fulfilled by an improved nursery bed. The low nutrient availability retards the seedling growth.

Discolouration of leaves or leaf yellowing in rice seedlings is a very common problem under low-temperature stress during the winter season [44,45], whichis also supported by our findings. Low chlorophyll content in soybeans due to cold stress was also reported by Yadegari et al. [46], who concluded that the low photosynthetic rate due to suboptimal temperature during early boro might be the reason forthe low chlorophyll content. In addition, leaf chlorophyll content was reduced with an increase in stress and cold injury due to higher electrolytic leakage [47,48].

The membrane stability may be damaged when seedlings are exposed to cold stress $[49,50]$. Exposurestolow temperatures also prolonged the growth duration of seedlings, and therefore more time was required to keep the seedlings in the nursery beds, as reported by [51]. A similar trend of observation was found in our experiment.

Additionally, rice-dominant regions are more prone to $\mathrm{Zn}$ deficiency, which favour schlorosis, necrosis, early death of seedlings, or delayed development in the nursery bed [52]. Supplementation of $\mathrm{Zn}$ and B improves the starch accumulation in seedling leaves, and the former has a beneficial effect on soil microorganisms, resulting in better $\mathrm{N}$ recycling and transforming the soil organic $\mathrm{N}$ into an inorganic form, which can easily be uptaken by rice seedlings [53]. Moreover, the synergistic relationship between $\mathrm{Zn}$ application and root development [53] might be the vital reason for the better growth and nutritional quality of seedlings grown under improved technology. An obvious role of $\mathrm{Zn}$ in chlorophyll formation resulted in a greater SPAD value of improved seedling leaves, and our findings are in accordance with Zulfiqar et al. [54]. Application of $\mathrm{Zn}$ and B maintain the cell integrity and membrane stability [54], which undoubtedly accelerated the growth and survival rate of winter rice seedlings in the present study.

A favourable growing environment under polythene covering accelerated seedling growth, which reduced the seedling retention time in the nursery bed (Table 8 ). The prerequisite of a low time in raising seedlings lowered the input use in terms of manpower and irrigation supply. Additionally, early-age transplantation helps in the easy acclimatization of seedlings in the main field, and a longer duration in the nursery bed has greaterintense transplanting shock because of greater root damage probability [55]. Previous researchers also supported that younger seedlings ensured higher panicle count, grain yield and better grain quality $[9,22,55]$. The prevention of direct evaporation from polythene-protected 
plots might be a reason for low water demand. Ultimately, low input use and time duration resulted in greater low-cost involvement along with energy utilization in farming activities (Figure 8) than the conventional way. Similar findings were also observed by Mondal et al. [20].

\section{Conclusions}

After evaluating the seedbed management techniques for two successive years during the winter season, this research recommended that the nursery bed should be covered with a transparent polythene sheet at a certain height to protect the seedlings from cold waves, fog, and low humidity. Furthermore, sowing well pre-germinated seeds in the nursery bed along with micro-nutrient supplementation is highly advocated. The improvedmethodology saved time (20 days), labour ( 2 times), water (2 times), and cost of production ( 2.3 times) along with farm energy input ( 1.15 times). The seedbed with improved technology yielded $20.32 \%$ and $24.27 \%$ higher seedlings with greater chlorophyll content and nutrient accumulation. The present experiment also successfully demonstrated rice seed germination through a cost-effective accessible germinator. In the conventional method, where seedlings have to be kept for almost 45 days in the winter season, whereas the present recommendation performs the seedling transplantation at 25 DAS, which could help to easily overcome the transplanting shock and favor the early harvesting from the main field before commencing the heat stress and cyclonic effects at the physiological maturity stage. However, proper monitoring and work precision are needed to raise the seedlings within a short period. Improper disposal of used polythene sheets might be problematic in soil health. In the future, this research could be validated with different agroclimatic regions, particularly in extremely low temperatures with various types of covering materials and seed priming approaches.

Author Contributions: Conceptualization, M.M., B.B., S.A., P.K.B. and S.G.; methodology, M.M., S.G., S.S., H.B. and B.B.; soft-ware, M.M., S.G., T.K.M. and A.H.; validation, M.M., S.G., S.S., H.B. and B.B.; formal analysis, M.M., S.G., S.M. and A.H.; investigation, M.M., S.G., S.S. and H.B.; resources, B.B., H.B., A.G., Y.S.A., B.M.R. and A.H.; data curation, M.M., S.G., S.S., A.H. and S.M.; writing-original draft preparation, M.M., S.G., S.A., S.S., K.B., H.B. and A.H.; writing-review and editing B.B., S.M., K.B., H.B., A.G., Y.S.A., B.M.R. and A.H.; visualization, M.M., T.K.M., S.G. and S.S.; supervision, B.B., T.K.M., P.K.B. and H.B.; project administration, B.B., A.G., Y.S.A., B.M.R. and A.H.; funding acquisition, A.H., A.G. and Y.S.A. All authors have read and agreed to the published version of the manuscript.

Funding: This research was funded by Bidhan Chandra KrishiViswavidyalaya, Gayeshpur, West Bengal, India and also partially supported by the Taif University Researches Supporting Project number (TURSP 2020/78), Taif University, Taif, Saudi Arabia.

Institutional Review Board Statement: Not applicable.

Informed Consent Statement: Not applicable.

Data Availability Statement: Data arenot publicly available, though the data may be made available on request from the corresponding author.

Acknowledgments: The authors acknowledge the Bidhan Chandra Krishi Viswavidyalaya, Gayeshpur, West Bengal, India for supporting a PhD scholarship for the first author and financial support to conduct this study. The authors also extend their appreciation to the Taif University Researches Supporting Project number (TURSP 2020/78),Taif University, Taif, Saudi Arabia for partially supporting the study.

Conflicts of Interest: The authors declare no conflict of interest. 


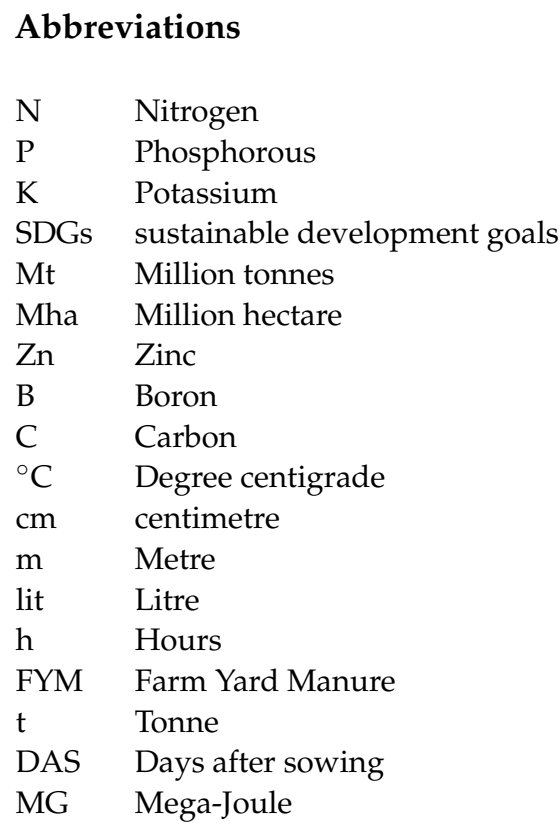

\section{Appendix A}

Table A1. Energy equivalents for different inputs in seedbed preparation.

\begin{tabular}{ccc}
\hline Item & Unit & Energy (MJ) \\
\hline Human labour (Adult man) & Man-hour & 1.96 \\
Bullocks (Medium) & Pair-hour & 10.10 \\
Diesel & Litre & 56.31 \\
Machinery & $\mathrm{kg}$ & 64.80 \\
$\mathrm{FYM}$ & tonne & 300 \\
$\mathrm{~N}$ & $\mathrm{~kg}$ & 60.60 \\
$\mathrm{P}_{2} \mathrm{O}_{5}$ & $\mathrm{~kg}$ & 11.10 \\
$\mathrm{~K}_{2} \mathrm{O}$ & $\mathrm{kg}$ & 6.70 \\
$\mathrm{Zn}$ & $\mathrm{kg}$ & 120 \\
$\mathrm{~B}$ & $\mathrm{~kg}$ & 120 \\
Rice seed & $\mathrm{kg}$ & 14.7 \\
Polythene mulching & Pound (lb) & 20.99 \\
\hline
\end{tabular}

MJ—Mega Joule; Source: Zahedi et al. [56].

\section{References}

1. FAO. FAOSTAT Database Collections. Food and Agriculture Organization of the United Nations: Rome. 2021. Available online: http:/ / www.fao.org/faostat/en/\#data/QC/visualize (accessed on 6 July 2021).

2. Muthayya, S.; Sugimoto, J.D.; Montgomery, S.; Maberly, G.F. An overview of global rice production, supply, trade, and consumption. Ann. N. Y. Acad. Sci. 2014, 1324, 7-14. [CrossRef]

3. Biswas, B.; Chakraborty, D.; Timsina, J.; Roy, D.P.D.; Adhikary, S.; Das, I.; Sarkar, A.; Ray, B.R.; Sarkar, S.; Mondal, M.; et al Replacing winter rice in non-traditional areas by strawberry reduces arsenic bioaccumulation, and improves water productivity and profitability. Sci. Total Environ. 2021, 788, 147810. [CrossRef] [PubMed]

4. Biswas, B.; Timsina, J.; Garai, S.; Mondal, M.; Banerjee, H.; Adhikary, S.; Kanthal, S. Weed control in transplanted rice with post-emergence herbicides and their effects on subsequent rapeseed in Eastern India. Int. J. Pest Manag. 2020. [CrossRef]

5. GOI. Agricultural Statistics at Glance. In Government of India, Ministry of Agriculture, Cooperation and Farmers Welfare, Directorate of Economics and Statistics; GOI: New Delhi, India, 2019; Available online: https:/ /agricoop.nic.in/en/annual-report (accessed on 15 April 2021).

6. Sudhir-Yadav; Kumar, V.; Singh, S.; Kumar, R.M.; Sharma, S.; Tripathi, R.; Nayak, A.; Ladha, J.K. Growing Rice in Eastern India: New Paradigms of risk reduction and improving productivity. In The Future Rice Strategy for India; Mohanty, S., Chengappa, P., Mruthunjaya, H., Ladha, J.K., Baruah, S., Kannan, E., Manjunatha, A.V., Eds.; Elsevier: London, UK, 2017; pp. $221-258$.

7. Banerjee, H.; Samanta, S.; Sarkar, S.; Garai, S.; Pal, S.; Brahmachari, K. Growth, Productivity and Nutrient Uptake of Different Rice Cultivars under Coastal Eco-System of West Bengal. J. Indian Soc. Coast. Agric. Res. 2018, 36, 115-121. 
8. Kundu, R.; Mondal, M.; Garai, S.; Mondal, R.; Poddar, R. Bio-efficacy of post emergence herbicides in boro rice nursery as well as main field and their residual effects on non-target microorganisms. Oryza 2020, 57, 199-210. [CrossRef]

9. Priyanka, K.; Jaiswal, H.K. Effect of cold stress on boro rice seedlings. J. Appl. Nat. Sci. 2017, 9, 1036-1041.

10. Pathak, A.K.; Pathak, P.K.; Sharma, K.K. Recent Development in Boro Rice Improvement and Production for Raising Rice Yield in Assam. In Boro Rice; Singh, R.K., Hossain, M., Thakur, R., Eds.; International Rice Research Institute: New Delhi, India, 2003; pp. 73-80.

11. Yoshida, S. Fundamentals of Rice Crop Science; International Rice Research Institute: Los Baňos, Phillipines, $1981 ;$ pp. 1-63.

12. Basuchaudhuri, P. Cold Tolerance in Rice Cultivation, 1st ed.; CRC Press: Boca Raton, FL, USA; Taylor \& Francis Group: Boca Raton, FL, USA, 2014; pp. 1-210.

13. Sharma, N.; Reinke, R.; Sacks, E.J. Comparison of Methods toEvaluate Rice (Oryzasativa) Germplasm for Tolerance to Low Temperature at the Seedling Stage. Agronomy 2021, 11, 385. [CrossRef]

14. Suh, J.P.; Lee, C.K.; Lee, J.H.; Kim, J.J.; Kim, S.M.; Cho, Y.C.; Park, S.H.; Shin, J.C.; Kim, Y.G.; Jena, K.K. Identification of quantitative trait loci for seedling cold tolerance using RILs derived from a cross between japonica and tropical japonica rice cultivars. Euphytica 2012, 184, 101-108. [CrossRef]

15. Biswas, B.; Timsina, J.; Patra, S.R.; De, D.; Mishra, B.; Chakraborti, R.; Patra, A.; Mahato, B.; Banerjee, P.; Ghosh, P.K.; et al. Climate Change-Resilient Rice Production Technology: A High Yielding, Water Efficient and Remunerative Option for South Asian Farmers. GJAAS 2019, 1, 20-29. [CrossRef]

16. Liu, Q.; Zhou, X.; Li, J.; Xin, C. Effects of seedling age and cultivation density on agronomic characteristics and grain yield of mechanically transplanted rice. Sci. Rep. 2017, 7, 14072. [CrossRef] [PubMed]

17. Mondal, M.; Skalicky, M.; Garai, S.; Hossain, A.; Sarkar, S.; Banerjee, H.; Kundu, R.; Brestic, M.; Barutcular, C.; Erman, M.; et al. Supplementing Nitrogen in Combination with Rhizobium Inoculation and Soil Mulch in Peanut (Arachishypogaea L.) Production System: Part I. Effects on Productivity, Soil Moisture, and Nutrient Dynamics. Agronomy 2020, 10, 1582. [CrossRef]

18. Ajeigbe, H.A.; Kamara, A.Y.; Kunhiya, A.; Inuwa, A.H.; Adinoyi, A. Response of Groundnut to Plant Density and Phsophorus Application in the Sudan Savanna Zone of Nigeria. Int. J. Biosci. 2016, 9, 291-320.

19. Mondal, M.; Skalicky, M.; Garai, S.; Hossain, A.; Sarkar, S.; Banerjee, H.; Kundu, R.; Brestic, M.; Barutcular, C.; Erman, M.; et al Supplementing Nitrogen in Combination with Rhizobium Inoculation and Soil Mulch in Peanut (Arachishypogaea L.) Production System: Part II. Effect on Phenology, Growth, Yield Attributes, Pod Quality, Profitability and Nitrogen Use Efficiency. Agronomy 2020, 10, 1513. [CrossRef]

20. Mondal, M.; Garai, S.; Banerjee, H.; Sarkar, S. Mulching and nitrogen management in peanut cultivation: An evaluation of productivity, energy trade-off, carbon footprint and profitability. Energy. Ecol. Environ. 2020, 6, 133-147. [CrossRef]

21. Begum, M.K.; Kader, M.A.; Hossain, S.M.A.; Hasan, K.M. Effect of seedling raising method and fertilizer combination on the yield of late boro rice. Pak. J. Agron. 2002, 1, 89-91. [CrossRef]

22. Kilic, H. The effect of planting methods on yield and yield components of irrigated spring durum wheat varieties. Sci. Res. Essays 2010, 5, 3063-3069. Available online: http:/ / www.academicjournals.org/SRE (accessed on 10 October 2021).

23. Mishra, A.; Salokhe, V.M. Seedling characteristics and the early growth of transplanted rice under different water regimes. J. Exp. Agric. 2008, 44, 1-19. [CrossRef]

24. Statista. Available online: https:/ / www.statista.com/statistics/1006969/india-number-of-cold-waves / (accessed on 6 July 2021)

25. Sharma, B.K.; Islam, M.S. Nursery Management in boro rice Seedling through different dates of Sowing. Int. Arch. App. Sci. Technol. 2020, 11, 156-160.

26. Bouyoucos, G.J. Hydrometer method improved for making particle size analyses of soils. Agron. J. 1962, 54, 464-465. [CrossRef]

27. Brady, N.C.; Weil, R.R. The Nature and Properties of Soils; Prentice Hall Inc: Hoboken, NJ, USA, 1996; pp. 1-1071.

28. Jackson, M.L. Soil Chemical Analysis; Prentice-Hall of India Pvt. Ltd.: New Delhi, India, 1967; pp. 1-498.

29. Walkley, A.J.; Black, I.A. An examination of the Degtjareff method for determining soil organic matter, and a proposed modification of the chromic acid titration method. Soil Sci. 1934, 37, 29-38. [CrossRef]

30. Subbiah, B.V.; Asija, G.L. A rapid procedure for estimation of available nitrogen in soil. Curr. Sci. 1956, 25, 259-260.

31. Olsen, S.R.; Cole, C.V.; Watanabe, F.S.; Dean, L.A. Estimation of available phosphorous in soil by extraction with sodium bicarbonate. USDA Circ. 1954, 939, 1-19.

32. Hanway, J.J.; Heidel, H. Soil analysis methods as used in Iowa State College Soil Testing Laboratory. Iowa State Coll. Agric. Bull. 1952, 57, 1-13.

33. Garai, S.; Brahmachari, K.; Sarkar, S.; Kundu, R.; Pal, M.; Pramanick, B. Crop Growth and Productivity of Rainy Maize-garden Pea Copping Sequence as Influenced by Kappaphycus and Gracilaria Saps at Alluvial Soil of West Bengal, India. Curr. J. Appl. Sci. Technol. 2019, 36, 1-11. [CrossRef]

34. Olasupo, F.O.; Ilori, C.O.; Forster, B.P.; Bado, S. Mutagenic Effects of Gamma Radiation on Eight Accessions of Cowpea (Vignaunguiculata [L.] Walp.). Am. J. Plant Sci. 2016, 7, 339-351. [CrossRef]

35. Kundu, R.; Mondal, M.; Garai, S.; Banerjee, H.; Ghosh, D.; Majumder, A.; Poddar, R. Efficacy of herbicides on weed control, rhizospheric micro-organisms, soilproperties and leaf qualities in tea plantation. Indian J. Weed Sci. 2020, 52, 160-168. [CrossRef]

36. IRRI. Statistical tool for agricultural research, Version 2.0.1. In User's Manual. Biometrics and Breeding Informatics; PBGB, Division, International Rice Research Institute: Los Bãnos, Philippines, 2013. 
37. Azhiri-Sigari, T.; Desamero, N.V.; Cabigat, J.C.; Abayao, E.H. Seedbed \& Seedling Management in the Ifugao Rice Terraces. Philipp. J. Crop. Sci. 2004, 29, 45-50.

38. Kumar, A.; Reddy, M.D. Effect of nursery seeding date and phosphorus fertilization on rice seedling growth. IRRN 2003, 282, 50-52.

39. Shah, M.H.; Amarjit, S.B.; Bali, A.S.; Singh, K.N. Studies on sowing dates and systems of rice nursery raising to combat cold injury in temperate Kashmir. Oryza 2000, 37, 96-99.

40. Rautaray, S.K. Effect of nursery density and polythene tunnel on seedling vigour and yield of Boro rice (Summer) in lower Assam. Indian Farming 2003, 53, 28-31.

41. Yoshida, S. Tropical Climate and Its Influence on Rice; IRRI: Los Banos, Philippines, 1978.

42. Maheswari, J.; Margatham, N.; Martin, G.J. Relatively simple irrigation scheduling and N application enhances the productivity of aerobic rice (Oryzasativa). Am. J. Plant Physiol. 2007, 2, 261-268. [CrossRef]

43. Rashid, M.M.; Yasmeen, R. Cold Injury and Flash Flood Damage in Boro Rice Cultivation in Bangladesh: A Review. Bangladesh Rice J. 2017, 21, 13-25. [CrossRef]

44. Aghaee, A.; Moradi, F.; Zare-Maivan, H.; Zarinkamar, F.; Irandoost, H.P.; Sharifi, P. Physiological responses of two rice (Oryzasativa L.) genotypes to chilling stress at seedling stage. Afr. J. Biotechnol. 2011, 10, 7617-7621.

45. Jan, M.; Shinwari, K.I.; Shah, G.; Khan, M.H.U.; Ullah, S.; Hameed, A.; Malook, I. Consequences of short-term low temperature stress on physiological and biochemical aspects of rice (Oryzasativa L.). Sci. Agric. 2015, 10, 1-14.

46. Yadegari, L.Z.; Heidari, R.; Carapetian, J. The influence of cold acclimation on proline, malondialdehyde (MDA), total protein and pigments contents in soybean (Glycine max) seedling. J. Biol. Sci. 2007, 7, 1141-1436. [CrossRef]

47. Petrov, P.I.; Kocheva, K.V.; Petrova, A.S.; Georgiev, G.I. Ion leakage and leaf anatomy of barley plants subjected to dehydration. Genet. Plant Physiol. 2015, 2, 15-23.

48. Jahan, M.S.; Nozulaidi, M.B.N.; Moneruzzaman, M.K.; Ainun, A.; Husna, N. Control of plant growth and water loss by a lack of light-harvesting complexes in photosystem-II in Arabidopsis thaliana ch1-1 mutant. Acta Physiol. Plant. 2014, 36, 1627-1635. [CrossRef]

49. Yamada, T.; Jones, E.S.; Congan, N.O.; Vecchies, A.C.; Nomura, T.; Hisano, H. QTL analysis of morphological, developmental, and winter hardiness-associated traits in perennial ryegrass. Crop. Sci. 2004, 44, 925-935.

50. Habibi, F.; NormahamadiSharifabad, H.; Eivazi, A.; Heravan, M. Effect of cold stress on cell mem-brane stability, chlorophyll a and $\mathrm{b}$ contain and proline accumulation in wheat (Triticumaiestivum L.) variety. Afr. J. Agric. Res. 2011, 6, 5854-5859. [CrossRef]

51. Kabir, M.S.; Howlader, M.; Biswas, J.K.; Mahbub, M.A.A.; Nur-E-Elahi, M. Probability of Low Temperature Stress at Different Growth Stages of Boro Rice. Bangladesh Rice J. 2015, 19, 19-27. [CrossRef]

52. Nadeem, F.; Farooq, M. Application of micronutrients in rice-wheat cropping systems of South Asia: A review. Rice Sci. 2019, 26, 356-371. [CrossRef]

53. Khan, M.U.; Qasim, M.; Subhan, M.; Ahmad, R.D.; Ali, L. Effect of zinc application by different methods on the chemical composition and grain quality of rice. Pak. J. Appl. Sci. 2003, 3, 530-536. [CrossRef]

54. Zulfiqar, U.; Hussain, S.; Ishfaq, M.; Matloob, A.; Ali, N.; Ahmad, M.; Alyemeni, M.N.; Ahmad, P. Zinc-Induced Effects on Productivity, Zinc Use Efficiency, and Grain Biofortification of Bread Wheat under Different Tillage Permutations. Agronomy 2020, 10, 1566. [CrossRef]

55. Lampayan, R.; Xangsayasane, P.; Bueno, C. Crop performance and water productivity of transplanted rice as affected by seedling age and seedling density under alternate wetting and drying conditions in Lao PDR. Water 2019, 11, 1816. [CrossRef]

56. Zahedi, M.; Mondani, F.; Eshghizadeh, H.R. Analyzing the energy balances of double-cropped cereals in an arid region. Energy Rep. 2015, 1, 43-49. [CrossRef] 